\title{
E-sigaretter -
}

\section{et viktig virkemiddel mot røykeskader}

\author{
E-sigaretter kan være et godt alternativ til vanlige sigaretter, noe som kan spare mange tapte leveår \\ og helsekroner. Dessverre ønsker helseministeren og sentrale helsemiljøer å begrense tilgangen.
}

Jeg behandler daglig pasienter med alvorlig røykerelatert sykdom, gir råd om røykeslutt og reduksjon av sigarettforbruk, og har vært begeistret for muligheten for nå å kunne tilby nok et middel for røykereduksjon, e-sigaretten. Mitt inntrykk ut fra egen praksis er at e-sigaretter og snus er mer attraktivt for erfarne røykere enn plaster og nikotintyggegummi.

Jeg undrer meg derfor over den betydelige motstanden vår helseminister, Folkehelseinstituttet og erfarne kolleger har vist mot å legalisere e-sigaretter. Senest i diskusjonen i Tidsskriftet i sommer fremstilles e-sigaretter nærmest som en stimulus til fortsatt røyking $(1,2)$. Kampen mot tobakk er i denne diskusjonen blitt til en kamp mot all nikotin, hvor vi risikerer å vinne slaget, men tape krigen.

\section{Tapte leveår}

Røyking forårsaker hjerteinfarkt og slag og er den viktigste årsaken til lungekreft. I tillegg er røyking en viktig årsak til kreft i munnhule, svelg, spiserør, magesekk, bukspyttkjertel og urinveier. Helsedirektoratet anslår at røyking forårsaker 8000 dødsfall og 150 000-180 000 tapte kvalitetsjusterte leveår hvert år og at de samfunnsøkonomiske kostnadene ved røyking er opp mot 80 milliarder kroner per år $(3,4)$. Det røykes 4-5 milliarder sigaretter i Norge hvert år. Dette betyr at hver røykte sigarett svarer til ca. 15 tapte kvalitetsjusterte leveminutter og følgelig at en gjennomsnittsrøyker har tapt ett kvalitetsjustert leveår etter 6-7 års røyking.

I en artikkel i NRK Ytring i august 2014 uttalte presidenten i Legeforeningen og direktør ved Folkehelseinstituttet at vi bør fase ut røyketobakk innen 2035 (5). I en oppfølgingsartikkel i Bergens Tidende er helseminister Høie sitert på at han ser for seg at med aktive politiske tiltak er røykeepidemien over i 2050 (6). Hvis vi multipliserer 150000 tapte kvalitetsjusterte leveår og 8000 dødsfall per år med Legeforeningens/Folkehelseinstituttets 20 år og helseministerens 35 års ventetid, blir det grovt regnet 150 000-200 000 dødsfall og 3-4 millioner tapte kvalitetsjusterte leveår.

\section{E-sigaretter er lite farlig}

For å sette det på spissen: Det er røyking av tobakk som er farlig, i mye mindre grad tobakk i seg selv. Tobakk er ikke ufarlig, men kreft oppstår først og fremst når dette organiske materialet varmes opp til $700{ }^{\circ} \mathrm{C}$ i sigarettgloen og trekkes ned i lungene (7). Selv om tobakk har vært i bruk i 500 år i Europa, var lungekreft en meget sjelden kreftform før oppfinnelsen av sigarettproduksjonsmaskinene på slutten av 1800tallet (8).

Vi har nå fått utmerkede sigaretterstatningsprodukter som tyggegummi, snus og e-sigaretter som alle er tilnærmet ufarlige sammenlignet med røyking. Og disse skulle

\section{«Tillat omsetting \\ av e-sigaretter med smakstilsetning og underlegg disse innholdskontroll»}

tilfredsstille de fleste behov bortsett fra å rulle rullingsen og stappe pipen. Så hvis vi ikke trenger å forby tobakk ennå, er det på tide å gjøre alt man kan for å redusere røyking. Her teller hver sigarett.

\section{Råd til helseministeren}

E-sigaretter inneholder kontrollerbare kjemiske substanser og trenger i prinsippet ikke inneholde noen skadelige stoffer utover nikotin. I dag er e-sigaretter forbudt omsatt her til lands og derfor uregulert, og vi risikerer dermed at mange på egenhånd vil importere skadelige typer fra useriøse produsenter. Vi bør heller gjøre som England, som etter en gjennomgang av dagens forskning vil tillate e-sigaretter neste år (9). Ifølge nyhetene kan regjeringen komme til å tillate en smaksfri versjon neste år, men denne vil nok dessverre ikke appellere til gruppen som trenger det mest (10). Tilsvarende er allerede lovlig omsatt som legemiddel, og har liten utbredelse.

Mine råd til helseministeren er derfor: Tillat omsetting av e-sigaretter med smakstilsetning og underlegg disse innholdskontroll, gjerne gjennom Legemiddelverket. Oppfordre røykere til å erstatte sigarettene med snus, e-sigaretter eller nikotintyggegummi. Og til slutt: øk avgifter på røyketobakk og senk avgifter på erstatningsproduktene. Målet for helsemyndighetene må ikke være et tobakksfritt samfunn innen
2050, men et sigarett- og røykfritt samfunn langt tidligere.

\section{Håkon Olav Leira}

hakon.o.leira@ntnu.no

Håkon Olav Leira (f. 1968) er overlege ved Lungeavdelingen, St. Olavs hospital og postdoktor ved Norges teknisk-naturvitenskapelige universitet. Forfatter har fylt ut ICMJE-skjemaet og oppgir ingen interessekonflikter.

Litteratur

1. Sanner T, Grimsrud TK. E-sigaretter - til skade eller nytte? Tidsskr Nor Legeforen 2015; 135: 959-61.

2. Folkehelseinstituttet. Bruk av e-sigaretter er ikke risikofritt. www. fhi.no/artikler/?id=114662 (5.11.2015)

3. Helsedirektoratet. Statistikk om røyking, bruk av snus og e-sigaretter. https://helsedirektoratet.no/ folkehelse/tobakk-royk-og-snus/statistikk-omroyking-bruk-av-snus-og-e-sigaretter (10.9.2015)

4. Helsedirektoratet. Samfunnsøkonomiske kostnader av røyking - En vurdering av metodikk og kostnadenes størrelsesorden.

https://helsedirektoratet.no/Sider/Samfunns\% C3\%B8konomiske-kostnader-av-r\%C3\%B8yking$\%$ E2\% $80 \% 93$-En-vurdering-av-metodikk-ogkostnadenes-st\%C3\%B8rrelsesorden.aspx (17.10.2015).

5. Fem skritt for folkehelsen. Ytring. www.nrk.no/ ytring/fem-skritt-for-folkehelsen-1.11881025 (9.2.2015).

6. Dyregrov S. Legeforeningen vil utfase salg av tobakk innen 2035. Bergens Tidende 6.10.2014. www.bt.no/sprek/Legeforeningen-vil-utfase-salg av-tobakk-innen-2035--3206990.html (9.2.2015).

7. Chemistry and toxicology of cigarette smoke and biomarkers of exposure and harm. I: How tobacco smoke causes disease: The biology and behavioral basis for smoking-attributable disease: A report of the surgeon general. Atlanta, GA: Centers for Disease Control and Prevention, 2010.

8. Adler I. Primary malignant growths of the lung and bronchi: a pathologic and clinical study. London: Longmans, Green and Company, 1912.

9. Choices NHS. Some types of e-cigarettes to be regulated as medicines. www.nhs.uk/news/2013/ 06June/Pages/e-cigarettes-and-vaping.aspx

10. NTB. Regjeringen vil behandle e-sigaretter som vanlig røyk. www.dn.no/nyheter/politikkSamfunn/ 2015/10/26/1320/regjeringen-vil-behandleesigaretter-som-vanlig-ryk (5.11.2015).

Mottatt 17.10. 2015, første revisjon innsendt 20.11. 2015, godkjent 25.11. 2015. Redaktør: Martine Rostadmo.

Publisert først på nett. 